\title{
Magdalena Czubak-Koch, Uczenie się w kulturze miejsca pracy, Wydawnictwo Naukowe Dolnośląskiej Szkoły Wyższej, Wroc- law 2014, ss. 216.
}

Publikacja Uczenie się $w$ kulturze miejsca pracy jest monografią, która ukazała się w 2014 r., stanowi opracowanie dysertacji doktorskiej, która powstała pod opieką naukową prof. Mieczysława Malewskiego.

Autorka osadza uczenie się w społecznym kontekście miejsca pracy. Powołując się na słowa Petera L. Bergera i Thomasa Luckmana, że każda istota ludzka wchodzi w stosunki nie tylko ze środowiskiem, ale i „z dokładnie określonym porządkiem kulturowym i społecznym, który jest jej dostępny za pośrednictwem znaczących innych [...]" (s. 8), Magdalena Czubak-Koch na środowisko pracy patrzy przez pryzmat kultury. Uważa, że każde miejsce pracy posiada swoją specyficzną kulturę organizacji, której istotą jest poczucie wspólnoty codziennych praktyk oraz podzielanie wspólnych wartości i norm. Tak rozumiane uczenie się związane jest z praktykowaniem, dlatego Autorka chce spojrzeć na miejsce pracy jak na obszar wspólnego działania grupy ludzi (s. 8). Przedmiot poznania wynika z przyjętej w pracy perspektywy społeczno-kulturowej. Autorka uznaje, że aktywność człowieka w miejscu pracy nie kończy się na wykorzystywaniu zdobytej przez niego wiedzy i umiejętności w określonym środowisku i stawia jej zdaniem dużo istotniejsze pytanie o to, w jaki sposób zdobywana jest nowa wiedza i umiejętności, jakie wydarzenia i sytuacje w środowisku pracy skłaniają ludzi do uczenia się? (s. 14).

Magdalena Czubak-Koch lokuje swoje przedsięwzięcie badawcze w praktyce badania świata pracy jako tekstu kultury i społecznego uczenia się ${ }^{*}$ Książka zorientowana jest na ukazanie złożoności i wieloaspektowości uczenia się w miejscu pracy. Świat pracy nie jest bytem stałym, jest światem

* $\quad$ Z recenzji dr hab. Alicji Jurgiel-Aleksander, [w:] M. Czubak- Koch, Uczenie się w kulturze miejsca pracy, Wydawnictwo Naukowe DSW, Wrocław 2014, okładka. 
społecznym, który jest konstruowany przez działania i wzajemne oddziaływania ludzi, co za tym idzie, uczenie się jest podstawą każdej aktywnosći w miejscu pracy (s. 14).

Część teoretyczna książki składa się z dwóch rozdziałów. W pierwszym $z$ nich Autorka koncentruje się na scharakteryzowaniu pojęcia „kultury organizacji”, które jest przedmiotem zainteresowania specjalistów zarówno humanistyki, jak i dyscyplin z obszaru zarządzania i przedsiębiorczości. Autorka podkreśla w tekście różnorodność przyjmowanych stanowisk teoretycznych oraz analizuje kulturowy wymiar środowiska pracy jako specyficzną przestrzeń uczenia się.

W drugim rozdziale Autorka stara się patrzeć na środowisko pracy jako na miejsce wspólnego działania ludzi, w którym poprzez interakcje z innymi uczestnikami zachodzi uczenie się. W rozdziale tym opisano teoretyczną koncepcję uczenia się sytuacyjnego Jeane Lave i Etienne’a Wengera. Koncepcja ta została zastosowana na gruncie myśli andragogicznej, stwarzając możliwość przeniesienia „punktu cieżkości” uczenia się z instytucji oświatowych na działania jednostek i społeczności. Teoria stanowi dobry fundament dla zrozumienia oraz wyjaśnienia warunków i sposobów uczenia się człowieka w środowisku pracy dlatego pytania o to, czego i w jaki sposób uczą się ludzie w miejscu pracy Autorka osadza na jej gruncie.

Trzeci rozdział to prezentacja założeń metodologicznych i przyjętej procedury badawczej. Celem prezentowanych badań jest poznanie, zrozumienie czy opisanie sposobów uczenia się człowieka dorosłego w środowisku pracy. Pytanie badawcze, które stawia Autorka brzmi: czego i w jaki sposób uczq się ludzie $w$ środowisku pracy? (s. 87). Poszukiwania interesujących ją procesów uczenia się upatruje w ludzkich zachowaniach, w relacjach między działającymi ludźmi i trakuje je jako interaktywny i dynamiczny proces, „dziejący się w środowisku społeczno-kulturowym zakładu pracy” (s. 87). Badaczka patrzy na środowisko pracy przez pryzmat kultury (co jest szczególnie istotne, ponieważ „z niej” wynikają różnego rodzaju warunki, sytuacje i zdarzenia związane $z$ uczeniem się) i przyjmuje paradygmat interpretatywny, którego założenia pozwalają na przyjrzenie się kulturowo uzgodnionej rzeczywistości miejsca pracy, na wyłonienie podobieństw w myśleniu, działaniu i odczuwaniu różnych sytuacji i zrozumienie sensów, a także znaczeń, jakimi posługują się działający uczestnicy (s. 88). Badania zostały oparte na schemacie etnograficznym. Dla realizacji celu badań Autorka zastosowała technikę obserwacji uczestniczącej, przyjmując rolę pełnego uczestnika społeczności. Przyjęcie takiej roli wymaga od badacza „dwojakiego” rodzaju uczenia się - nauczenia się w roli pracownika, a następnie interpretacji tego 
doświadczenia. Badaczka rozwiązała ten dylemat przyjmując rolę „refleksyjnego praktyka”. Po zakończeniu „uczestniczącego” etapu badaczka zrealizowała drugi etap, polegający na przeprowadzeniu wywiadów (na podstawie kwestionariusza) z pracownikami firmy. Poza terenem badań Autorka prowadziła dziennik badacza, w którym charakteryzowała codzienność, zaobserwowane zdarzenia, wypowiedzi, „zwroty sytuacyjne” i zachowania niewerbalne, ale także zapisywała doświadczenia, emocje, obawy, problemy badaczki (s. 106).

W rozdziale czwartym Czytelnik znajdzie interpetację wyników badań. Odwołując się do teorii uczenia się sytuacyjnego, Autorka prezentuje cztery wymiary uczenia się w środowisku pracy. Przedstawia bariery w uczeniu się oraz typologię stylów uczenia się skonstruowaną w oparciu o zgromadzony materiał badawczy. Stworzona typologia stylów uczenia się to wynik poszukiwania przez Autorkę interesujących Ją sposobów uczenia się w miejscu pracy. Wyłoniła strategie jednostkowych działań, które ilustrują style uczenia się: efektywny, styl symulatywny, styl letargiczny. Pierwszy z nich cechuje zarówno wysoka świadomość społecznych procesów uczenia się, jak i aktywności zorientowanej na cel. Przedstawiciele symulatywnego stylu uczenia się korzystają głównie z doświadczenia i cechuje ich raczej niska motywacja do uczenia się nowych rzeczy. W sytuacjach, które wymagają poszukiwania nowych sposobów rozwiązania problemów, umiejętnie stosują wyuczone strategie „unikania”. Styl letargiczny charakteryzuje się niskim stopniem świadomości naturalnych procesów uczenia sie i nikłym zaangażowaniem w działanie.

Na szczególną uwagę zasługuje Aneks Uczenie się badacza, który jest interesującą próbą opisu doświadczeń i refleksji wyniesionych przez badacza występującego w roli obserwatora uczestniczącego.

Na rynku wydawniczym istnieją publikacje poświęcone: organizacjom uczącym się, kulturom organizacyjnym przedsiębiorstw, procesom uczenia się w organizacjach itp., jednak prezentowana pozycja to obszerne, pogłębione, nowatorskie studium nad uczeniem się w organizacji, którego Autorka patrzy na pracę jako przestrzeń budowania rozmaitych doświadczeń edukacyjnych. Publikacja Magadaleny Czubak-Koch jest ważną, kompetentnie napisaną pracą, stanowiącą lekurę obowiązkową dla wszystkich tych, którzy chcą wiedzieć więcej o własnym uczeniu się wśród innych.

Anna Matusiak 